\title{
PROMOÇÃO DE SAÚDE BUCAL NOS MUNICÍPIOS DE GUARAQUEÇABA, GUARATUBA E ALMIRANTE TAMANDARÉ
}

Juliane MALUCELLI, José Luiz COSTA, Mariesa STANKIEWICZ, Susiane BASTOS, Marilene BUFFON

O presente projeto de extensão teve seu início em municípios do Vale do Ribeira e, por meio da crescente demanda de atenção à saúde bucal em outras regiões do Paraná e da ativa participação dos alunos bolsistas/voluntários, o projeto necessitou ser estendido para outros municípios como Guaraqueçaba, Guaratuba e Almirante Tamandaré. O objetivo foi promover ações de saúde bucal nestes municípios, permitindo com que o acadêmico de Odontologia da UFPR desenvolvesse não apenas habilidades, mas também ampla capacidade crítica e reflexiva necessárias à compreensão da realidade social, cultural e econômica do meio onde atuará, dirigindo sua formação para a transformação da realidade em benefício da coletividade. Atividades que foram desenvolvidas: educação em saúde bucal nos municípios litorâneos de Guaraqueçaba e Guaratuba com orientação e estímulo às crianças no controle do biofilme dental, ensino técnico de escovação e uso de fio dental; atividades lúdicas com as crianças do Centro de Educação Infantil Criança Feliz e crianças com necessidades especiais do Centro de Atenção Integral à Criança no município de Almirante Tamandaré, utilizando recursos como teatro de fantoches, macromodelos de arcadas dentárias. Nestas instituições do município de Almirante Tamandaré, também foi feita orientação e estímulo às crianças em higienização bucal.

Palavras-chave: saúde bucal; educação em saúde; escovação. 